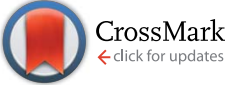

Cite this: RSC Adv., 2017, 7, 16387

Received 26th December 2016

Accepted 7th March 2017

DOI: 10.1039/c6ra28712c

rsc.li/rsc-advances

\section{HBT-based turn-on fluorescent probe for discrimination of homocysteine from glutathione/ cysteine and its bioimaging applications $\uparrow$}

\author{
Fengzao Chen, ${ }^{\mathrm{ab}}$ Zhen Chen, ${ }^{\mathrm{a}}$ Yuanchao Sun, ${ }^{\mathrm{a}}$ Heng Liu, ${ }^{\text {*a }}$ Deman Han, \\ Hanping He, ${ }^{a}$ Xiuhua Zhang ${ }^{a}$ and Shengfu Wang ${ }^{a}$
}

Based on ESIPT and heavy atom effect strategy, we firstly reported a new type of turn-on fluorescent probe for Hcy. This probe displayed fast response time (15 min), excellent selectivity over other interfering species and high sensitivity with a low detection limit of $1.6 \times 10^{-7} \mathrm{M}$ in PBS buffer containing $1 \% \mathrm{CH}_{3} \mathrm{CN}(\mathrm{v} / \mathrm{v})$. Moreover, the probe was also successfully applied for fluorescence imaging of Hcy in HeLa cells.

\section{Introduction}

Thiol-containing biomolecules, such as glutathione (GSH), homocysteine (Hcy) and cysteine (Cys) are important antioxidants in living organisms and play vital roles in many physiological and pathological processes. ${ }^{1}$ Studies have shown that abnormal levels of cellular thiols will lead to a series of health problems. ${ }^{2}$ Elevated Hcy levels could induce severe cardiovascular and Alzheimer's diseases, and mental disorders; ${ }^{3}$ the lack of Cys might cause metabolic diseases including hair loss, stunted growth, skin lesions and hematopoietic disorder; ${ }^{4}$ abnormal levels of GSH are closely associated with AIDS, cancer, cardiovascular disease, and inflammatory bowel disease. ${ }^{5}$ Therefore, monitoring the fluctuations of biothiol levels is of great significance for the early diagnosis and treatment of diseases.

In the past few years, a host of fluorescent probes for biothiols have been reported based on different sensing mechanisms, including Michael addition, ${ }^{6}$ nucleophilic substitution, ${ }^{7}$ addition-cyclization, ${ }^{8}$ cleavage reaction, ${ }^{9}$ metal complex-displace coordination. ${ }^{10}$ However, most of the reported fluorescent probe for biothiols took focus on distinguishing Cys from GSH/Hcy or distinguishing GSH from Cys/Hcy. Up till now, the probe that could discriminate Hcy from GSH/Cys was not only rare but also suffered from high detection limit, slow response time and high organic solvent volume ratio. ${ }^{11}$ Consequently, there is urgent need to develop

${ }^{a}$ Hubei Collaborative Innovation Center for Advanced Organic Chemical Materials, Ministry of Education Key Laboratory for the Synthesis and Application of Organic Functional Molecules, College of Chemistry and Chemical Engineering, Hubei University, Wuhan 430062, PR China. E-mail: liuheng11b@hubu.edu.cn ${ }^{b}$ Department of Chemistry, Taizhou University, Jiaojiang 318000, PR China

$\dagger$ Electronic supplementary information (ESI) available. See DOI: $10.1039 / \mathrm{c} 6 \mathrm{ra} 28712 \mathrm{c}$ more effective probes for selective discrimination of Hcy from GSH/Cys.

In this work, a novel turn-on fluorescent probe, namely HBTI, was firstly developed based on the excited state intramolecular proton transfer (ESIPT) and heavy atom effect strategy. In the design, the iodine moiety is not only a leaving group but also a quintessential fluorescence quencher. It could be easily replaced by the sulfhydryl group $(-\mathrm{SH})$ of biothiols, which will lead to the alteration of fluorescence intensity of the probe. However, due to the effect of different distances between -SH group and amido group ( $-\mathrm{NH}_{2}$ ) of Cys and $\mathrm{Hcy}, \mathrm{NH}_{2}$ group of Cys might further react with carbonyl of probe HBTI to form six-membered ring imine structure. The formed imine group would obviously weaken internal charge transfer (ICT) of the probe and result in the reduction of fluorescence intensity. In the presence of GSH, the probe exhibits the moderate fluorescence intensity due to the steric-hindrance effects. In addition, the probe can be successfully applied to the detection of Hcy in HeLa cells by fluorescence imaging.

\section{Experimental}

\section{Reagents and instruments}

All reagents and solvents were purchased from standard commercial suppliers and used without further purification. All the solutions were prepared with ultrapure water $\left(18.2 \mathrm{M} \mathrm{cm}^{-1}\right)$. All pH measurements were obtained on a PHS-3C (SCRPF E-201C). Column chromatography involved 200-300 mesh silica gel. All of the reactions were magnetically stirred and monitored by thin-layer chromatography (TLC) using UV light. All the spectra were measured in a quartz cuvette with $10.0 \mathrm{~mm}$ path length (volume: $3.5 \mathrm{ml}$ ). UV-vis absorption spectra were obtained on a Shimadzu UV-2700 spectrophotometer. Fluorescence emission spectrum and relative fluorescence intensity were acquired on a Shimadzu RF-5301 spectrofluorimeter. The excitation wavelength was $385 \mathrm{~nm}$ for all fluorescence measurements and 
the excitation/emission slit width set at $3 \mathrm{~nm} .{ }^{1} \mathrm{H}$ NMR and ${ }^{13} \mathrm{C}$ NMR spectra were recorded on a BRUKER 400 spectrometer with tetramethylsilane (TMS) as internal standard. LC-MS (ESI) was measured with an Agilent 6224 Liquid Chromatography Mass Spectrometer. Cells images were obtained using CLSM TCS SP5 (Leica, Germany).

\section{Synthesis}

Preparation and characterization of 1-(3-(benzo $[d]$ thiazol-2yl)-4-hydroxy phenyl)-ethanone (HBT-Ac). To a solution of 5acetyl-2-hydroxybenzaldehyde ( $97.0 \mathrm{mg}, 0.59 \mathrm{mmol}$ ), 2-aminothiophenol (73.6 $\mathrm{mg}, 0.59 \mathrm{mmol}$ ) and DMF $(5 \mathrm{ml})$, anhydrous sodium sulfate $(111.6 \mathrm{mg}, 7.08 \mathrm{mmol})$ was added and stirred at $110^{\circ} \mathrm{C}$ under nitrogen atmosphere. The progress of the reaction was monitored by TLC. After the reaction was completed, the organic mixture was poured into deionized water and extracted with ethyl acetate $(30 \mathrm{ml} \times 3)$. Then the collected organic phase that was dried with anhydrous sodium sulfate, filtered and concentrated in vacuo gave the original products. Purification by column chromatography (petroleum ether/ethyl acetate $8: 1$ ) gave desired product (128 mg, yield 81\%). ${ }^{1} \mathrm{H}$ NMR (400 MHz, $\mathrm{d}_{6}$-DMSO): $\delta 12.32(\mathrm{~s}, 1 \mathrm{H}), 8.86(\mathrm{~s}, 1 \mathrm{H}), 8.15(\mathrm{~d}, J=7.9 \mathrm{~Hz}, 1 \mathrm{H})$, $8.11(\mathrm{~d}, J=8.1 \mathrm{~Hz}, 1 \mathrm{H}), 8.01(\mathrm{dd}, J=8.6,2.2 \mathrm{~Hz}, 1 \mathrm{H}), 7.55(\mathrm{t}, J=$ $7.3 \mathrm{~Hz}, 1 \mathrm{H}), 7.46$ (t, $J=7.5 \mathrm{~Hz}, 1 \mathrm{H}), 7.18(\mathrm{t}, J=8.6 \mathrm{~Hz}, 1 \mathrm{H}), 2.60$ (s, 3H); ${ }^{13} \mathrm{C}$ NMR (100 MHz, d 6 -DMSO): $\delta$ 196.1, 163.2, 159.9, $151.4,134.9$, 132.4, 129.3, 128.9, 126.5, 125.2, 122.4, 122.0, 118.8, 116.9, 26.5; LC-MS TOF: calcd for $\mathrm{C}_{15} \mathrm{H}_{11} \mathrm{NO}_{2} \mathrm{~S}[\mathrm{M}+\mathrm{H}]^{+}$: 270.0510; found: 270.0665 .

Preparation and characterization of 1-(3-(benzo $[d]$ thiazol-2yl)-4-hydroxy phenyl)-2-iodoethanone (HBTI). Under nitrogen atmosphere, compound HBT-Ac (128 mg, $0.47 \mathrm{mmol}$ ) was dissolved in $\mathrm{MeOH}(15 \mathrm{ml})$. After the addition of cupric oxide (41 $\mathrm{mg}, 0.56 \mathrm{mmol}$ ) and iodine $(131 \mathrm{mg}, 0.52 \mathrm{mmol}$ ), the resulting mixture was refluxed for $2 \mathrm{~h}$. Reaction process was monitored by TLC. After the reaction was completed, the organic mixture was poured into deionized water and extracted with ethyl acetate $(30 \mathrm{ml} \times 3)$. Then the collected organic phase that was dried with anhydrous sodium sulfate, filtered and concentrated in vacuo gave the original products. Purification by column chromatography (petroleum ether/ethyl acetate $8: 1$ ) gave desired product (70 mg, yield 38\%). ${ }^{1} \mathrm{H}$ NMR $\left(400 \mathrm{MHz}, \mathrm{d}_{6}\right.$ DMSO): $\delta 12.47(\mathrm{~s}, 1 \mathrm{H}), 8.90(\mathrm{~s}, 1 \mathrm{H}), 8.15-8.10(\mathrm{~m}, 3 \mathrm{H}), 7.55(\mathrm{~s}$, $1 \mathrm{H}), 7.46(\mathrm{~s}, 1 \mathrm{H}), 7.19(\mathrm{~s}, 1 \mathrm{H}), 4.60(\mathrm{~s}, 2 \mathrm{H}) ;{ }^{13} \mathrm{C}$ NMR $(100 \mathrm{MHz}$, $\mathrm{d}_{6}$-DMSO): $\delta$ 191.7, 162.9, 160.1, 151.1, 134.7, 132.9, 129.9, 126.3, 125.1, 125.0, 122.2, 121.8, 118.9, 116.8, 4.48; HRMS: calcd for $\mathrm{C}_{15} \mathrm{H}_{10} \mathrm{INO}_{2} \mathrm{~S}[\mathrm{M}+\mathrm{H}]^{+}$: 395.9477 ; found: 395.9557 .

\section{General procedure for the spectra measurement}

The stock solution of probe $(0.5 \mathrm{mM})$ was prepared in acetonitrile $\left(\mathrm{CH}_{3} \mathrm{CN}\right)$. Solutions of the analytes including Ala, Arg, Asp, Glu, Gly, His, Ile, Leu, Lys, Met, Phe, Pro, Ser, Thr, Trp, Tyr, Val, $\mathrm{NaSH}$, Cys, Hcy, GSH, $\mathrm{Fe}\left(\mathrm{NO}_{3}\right)_{2}, \mathrm{Al}\left(\mathrm{NO}_{3}\right)_{3}, \mathrm{Mg}\left(\mathrm{NO}_{3}\right)_{2}, \mathrm{Zn}\left(\mathrm{NO}_{3}\right)_{2}$, $\mathrm{NaBr}, \mathrm{NaCl}, \mathrm{NaI}, \mathrm{NaF}, \mathrm{Na}_{2} \mathrm{CO}_{3}, \mathrm{NaHCO}_{3}, \mathrm{Na}_{2} \mathrm{HPO}_{4}, \mathrm{NaNO}_{2}$, $\mathrm{Na}_{2} \mathrm{SO}_{4}, \mathrm{Na}_{2} \mathrm{~S}_{2} \mathrm{O}_{3}, \mathrm{NaClO}, \mathrm{H}_{2} \mathrm{O}_{2}$ were prepared in ultrapure water. The resulting solution was kept at room temperature and then the absorption or fluorescence spectra were recorded.

\section{Cell culture and imaging}

HeLa cells were cultured in Dulbecco's Modified Eagle Medium (DMEM), fetal bovine serum (10\%), penicillin $\left(100 \mu \mathrm{g} \mathrm{ml}^{-1}\right)$ and streptomycin $\left(100 \mu \mathrm{g} \mathrm{ml} \mathrm{m}^{-1}\right)$ at $37^{\circ} \mathrm{C}$ in a $\mathrm{CO}_{2}$ incubator. In the fluorescence imaging experiment, the cells incubated with only probe HBTI $(10 \mu \mathrm{M})$ for $30 \mathrm{~min}$ at $37{ }^{\circ} \mathrm{C}$. In one control experiment, the cells were pretreated with $N$-ethylmaleimide for $30 \mathrm{~min}$ and then treated with probe HBTI $(10 \mu \mathrm{M})$ for another $30 \mathrm{~min}$. In another control experiment, the cells were treated with $\mathrm{N}$-ethylmaleimide for $30 \mathrm{~min}$ followed by treatment with the probe for $30 \mathrm{~min}$ and Hcy for $30 \mathrm{~min}$. The cells should be washed three times with PBS buffer before fluorescence imaging experiment with confocal laser scanning microscopy.

\section{Results and discussion}

\section{Spectral properties of probe HBTI}

With the probe HBTI in hand, we first examined its spectral properties. The free probe showed a weak fluorescence emission band in PBS buffer $\left(10 \mathrm{mM}\right.$, pH 7.4, containing $1 \% \mathrm{CH}_{3} \mathrm{CN}$, $\mathrm{v} / \mathrm{v}$ ) when it was excited at $385 \mathrm{~nm}$. The fluorescence quantum yield of the probe was 0.024 . After treating with $1 \mathrm{mM}$ Hcy, GSH and Cys separately, the fluorescence intensities at $445 \mathrm{~nm}$ of the probe were enhanced in varying degrees as shown in Fig. 1. Meanwhile, the fluorescence quantum yield increased to 0.31 , 0.22 and 0.19 , using 9,10-bis(phenylethynyl)-anthracene $\left(\Phi_{\mathrm{f}}=\right.$ 1.0 in cyclohexane) as a standard.

The fluorescence titration was investigated as illustrated in Fig. 2. As the amount of Hcy increased, an increasing enhancement of the fluorescence intensity at $445 \mathrm{~nm}$ was observed. When the concentration of Hcy ran up to $45 \mu \mathrm{M}$, the fluorescence intensity reached saturation. At the same time, a good linear correlation between the fluorescence emission intensity and the concentration of Hcy in the range of $0-30 \mu \mathrm{M}$ $\left(R^{2}=0.989\right)$ was obtained. The detection limit of probe HBTI for Hcy was calculated to $1.6 \times 10^{-7} \mathrm{M}$ on the basis of $\mathrm{S} / \mathrm{N}=3$. These results indicated probe HBTI could be served as a high

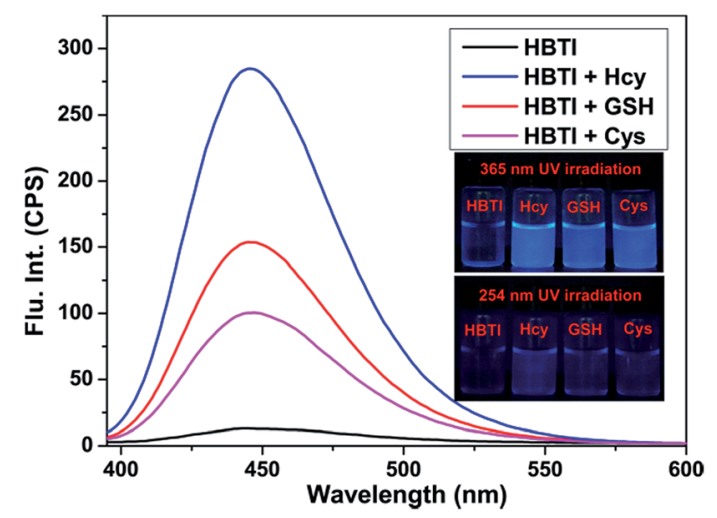

Fig. 1 Fluorescence spectra changes of probe $\mathrm{HBTI}(10 \mu \mathrm{M})$ prior to and after addition of Hcy, GSH, Cys (1 mM each) in PBS buffer (10 mM, $\mathrm{pH} 7.4$, containing $\left.1 \% \mathrm{CH}_{3} \mathrm{CN}, \mathrm{v} / \mathrm{v}\right)$ at $25^{\circ} \mathrm{C}$ for $15 \mathrm{~min}$. Inset photographs are $\mathrm{HBTI}$ with or without biothiols under UV irradiation. $E_{\mathrm{x}}=$ $385 \mathrm{~nm}, d_{\mathrm{ex}}=d_{\mathrm{em}}=3 \mathrm{~nm}$. 


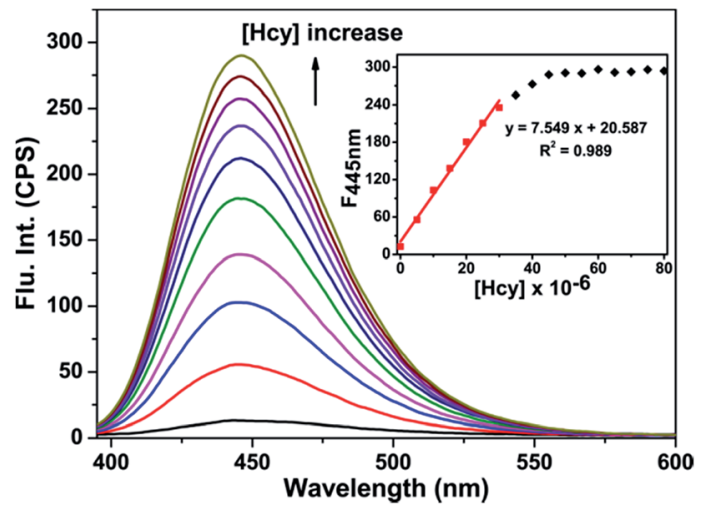

Fig. 2 Titration graph of the fluorescence response of probe HBTI (10 $\mu \mathrm{M})$ toward Hcy $(0-45 \mu \mathrm{M})$ in PBS buffer $(10 \mathrm{mM}, \mathrm{pH} 7.4$, containing $1 \%$ $\mathrm{CH}_{3} \mathrm{CN}, \mathrm{v} / \mathrm{v}$ ) at $25{ }^{\circ} \mathrm{C}$. Inset: plot of the fluorescence intensity at $445 \mathrm{~nm}$ of probe HBTI versus Hcy concentrations. Each spectrum was performed after $15 \mathrm{~min}$. $E_{\mathrm{x}}=385 \mathrm{~nm}, d_{\mathrm{ex}}=d_{\mathrm{em}}=3 \mathrm{~nm}$.

sensitive fluorescent probe for Hcy compared to the reported fluorescent probe (Table S1†). Similar fluorescence titrations of GSH and Cys to the probe solution were also investigated (Fig. S1 $\dagger$ ). And the detection limits for GSH and Cys were measured to be $4.0 \times 10^{-7} \mathrm{M}$ and $5.5 \times 10^{-7} \mathrm{M}$, respectively.

\section{Time-dependent fluorescence measures of the probe HBTI}

Next, the time-dependent fluorescence measures of the probe HBTI toward Hcy/GSH/Cys/NaSH were evaluated in PBS buffer (10 mM, pH 7.4, containing $1 \% \mathrm{CH}_{3} \mathrm{CN}, \mathrm{v} / \mathrm{v}$ ). As shown in Fig. 3, the fluorescence intensity at $445 \mathrm{~nm}$ of free probe HBTI kept almost unchange within $25 \mathrm{~min}$, suggesting that the probe had superior stability. Upon addition of Hcy, the fluorescence intensity gradually increased in the course of time and reached equilibrium at around $15 \mathrm{~min}$. Therefore, the response time of 15 min would be leveraged for the following experiments. The kinetic studies of the response of probe HBTI to Hcy, GSH and Cys were also performed in Fig. S2. $\uparrow$ The observed pseudo-firstorder rate constants $\left(K_{\text {obs }}\right)$ for Hcy, GSH and Cys were estimated

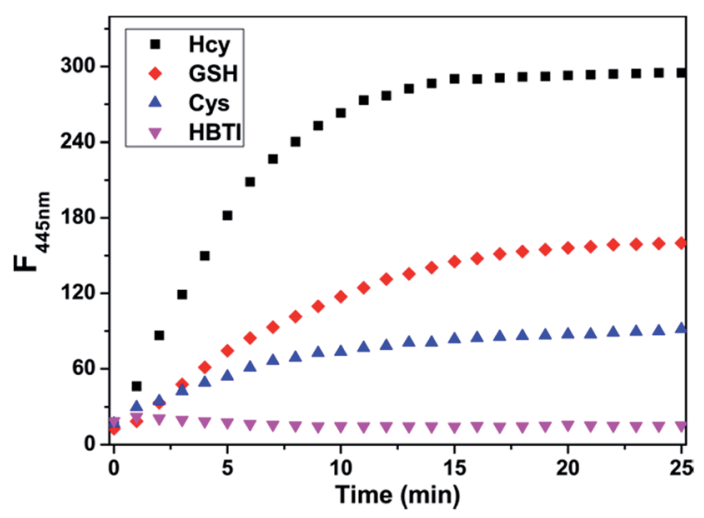

Fig. 3 Time-dependent fluorescence measures of probe HBTI $(10 \mu \mathrm{M}$, pink) after treatment with $50 \mu \mathrm{M}$ of Hcy (black), GSH (red), Cys (blue) in PBS buffer $\left(10 \mathrm{mM}, \mathrm{pH} 7.4\right.$, containing $\left.1 \% \mathrm{CH}_{3} \mathrm{CN}, \mathrm{v} / \mathrm{v}\right)$ at $25^{\circ} \mathrm{C} . E_{\mathrm{x}}=$ $385 \mathrm{~nm}, E_{\mathrm{m}}=445 \mathrm{~nm}, d_{\mathrm{ex}}=d_{\mathrm{em}}=3 \mathrm{~nm}$. to be $0.221 \mathrm{~min}^{-1}, 0.127 \mathrm{~min}^{-1}$ and $0.147 \mathrm{~min}^{-1}$, indicating that probe HBTI could be regarded as potential candidates for applications in detecting of biothiols.

\section{Effect of pH on the probe HBTI}

We also investigated the sensing performance of probe HBTI to biothiols under different $\mathrm{pH}$ values. As displayed in Fig. 4, there was almost no change in the fluorescence intensity of free probe HBTI within $\mathrm{pH}$ values ranging from 4.0 to 9.0, suggesting that the probe had good stability in a broad $\mathrm{pH}$ range. The fluorescence intensity of the probe appeared a slightly increase under alkaline conditions due to hydrolysis reaction of the iodine moiety. Furthermore, after adding $50 \mu \mathrm{M}$ Hcy to the solution of the probe, the fluorescence intensity at $445 \mathrm{~nm}$ showed a significant positive enhancement at the $\mathrm{pH}$ range of 6.0-9.0. Similar experimental phenomenons of GSH and Cys to the probe solution at different $\mathrm{pH}$ ranges were obtained. All these data demonstrated that probe HBTI could be used as an ideal Hcy probe in physiological environment.

\section{The selectivity of probe HBTI for Hcy}

It is well-known that the selectivity is a very important consideration in assessing the performance of as-prepared probe. Therefore, we evaluated the selectivity of probe HBTI toward Hcy over a series of biologically relevant analytes, including common amino acids (Ala, Arg, Asp, Glu, Gly, His, Ile, Leu, Lys, Met, Phe, Pro, Ser, Thr, Trp, Tyr, Val), ions $\left(\mathrm{Br}^{-}, \mathrm{Cl}^{-}, \mathrm{F}^{-}, \mathrm{I}^{-}\right.$, $\mathrm{CO}_{3}{ }^{2-}, \mathrm{HCO}_{3}{ }^{-}, \mathrm{HPO}_{4}{ }^{2-}, \mathrm{NO}_{2}{ }^{-}, \mathrm{SO}_{4}{ }^{2-}, \mathrm{S}_{2} \mathrm{O}_{3}{ }^{2-}, \mathrm{Al}^{3+}, \mathrm{Fe}^{2+}, \mathrm{Mg}^{2+}$, $\mathrm{Zn}^{2+}$ ) and reactive oxygen species $\left(\mathrm{ClO}^{-}, \mathrm{H}_{2} \mathrm{O}_{2}\right)$. As illustrated in Fig. S3, $\uparrow$ only the addition of Hcy, GSH, Cys and NaSH induced an increase of fluorescence intensity in different degrees while non-thiol-bearing amino acid had no discernible effect. Also, Fig $\mathrm{S} 4 \uparrow$ showed that the addition of various ions and redox species did not induce changes of fluorescence intensity of the probe. Furthermore, in order to explore the practical applicability of the probe, competitive experiment was performed in the presence of Hcy and other biologically relevant analytes.

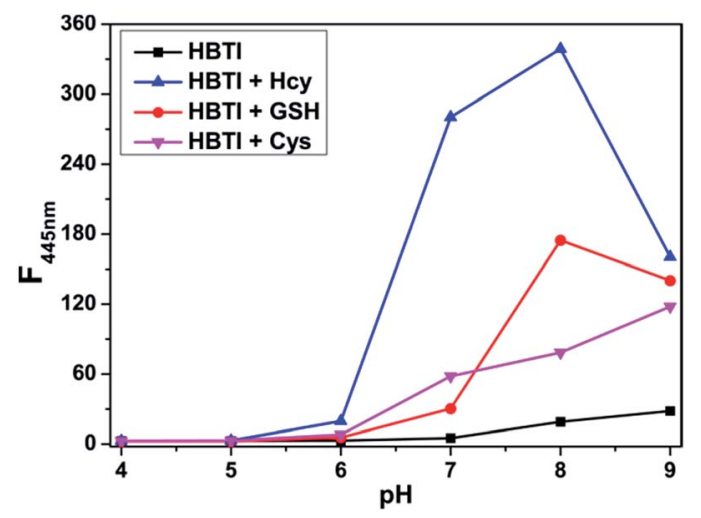

Fig. 4 Effect of $\mathrm{pH}$ on the fluorescence intensity of probe HBTI (10 $\mu \mathrm{M}$, black) after treatment with $50 \mu \mathrm{M}$ of Hcy (blue), GSH (red), Cys (pink) in PBS buffer ( $10 \mathrm{mM}, \mathrm{pH} 7.4$, containing $\left.1 \% \mathrm{CH}_{3} \mathrm{CN}, \mathrm{v} / \mathrm{v}\right)$ at $25^{\circ} \mathrm{C}$. $E_{\mathrm{x}}=385 \mathrm{~nm}, E_{\mathrm{m}}=445 \mathrm{~nm}, d_{\mathrm{ex}}=d_{\mathrm{em}}=3 \mathrm{~nm}$. 
Fig. 5 showed that almost no obvious influence on detection of Hcy was observed in the presence of coexisting non-thiolbearing amino acid. Although fluorescence intensity changed to different degrees after the addition of GSH, Cys and $\mathrm{NaSH}$, Hcy could still be identified from the extent of the enhanced fluorescence. All these results proved that probe HBTI possessed the capability of highly selective sensing Hcy and had the potential to be used to detect Hcy in complex physiological environment.

\section{Sensing mechanism}

In order to elucidate the sensing mechanism of probe HBTI, the ${ }^{1} \mathrm{H}$ NMR and ESI-MS spectrum analysis of probe HBTI with Hcy, GSH and Cys were conducted according to the literature. ${ }^{12}$ Upon excessive Hcy, GSH and Cys respectively, the ${ }^{1} \mathrm{H}$ NMR signal of aromatic hydrogen were apparently shifted to high-field with small shift, suggesting that the nucleophilic substitution of the sulfhydryl group with iodine moiety have been occurred (Fig. S5 $\dagger$ ). In addition, as illustrated in Fig. S6, $\dagger$ in the presence of excessive Hcy, GSH and Cys, the dominant peaks at $m / z=403.2,575.1$ and 371.1 could be attributed to $[\mathrm{HBTI}+\mathrm{Hcy}]^{+},[\mathrm{HBTI}+\mathrm{GSH}]^{+}$and $[\mathrm{HBTI}+\mathrm{Cys}]^{+}$respectively, which further supported the proposed sensing mechanism in Scheme 1.

\section{Fluorescence imaging of probe HBTI in living cells}

Inspired by the above experiment results, we next investigated the practicability of the probe in cellular imaging. The HeLa cells incubated with only probe HBTI $(10 \mu \mathrm{M})$ for $30 \mathrm{~min}$ at $37{ }^{\circ} \mathrm{C}$ showed weak blue fluorescence upon excitation at $405 \mathrm{~nm}$. In the control experiment, when the HeLa cells were pretreated with $N$-ethylmaleimide (NEM, $0.5 \mathrm{mM}$, a blocking reagent for thiol species) for $30 \mathrm{~min}$ and then treated with probe HBTI for another $30 \mathrm{~min}$, almost no blue fluorescence was detected. In another control experiment, after being preincubated with NEM for $30 \mathrm{~min}$, the HeLa cells were further

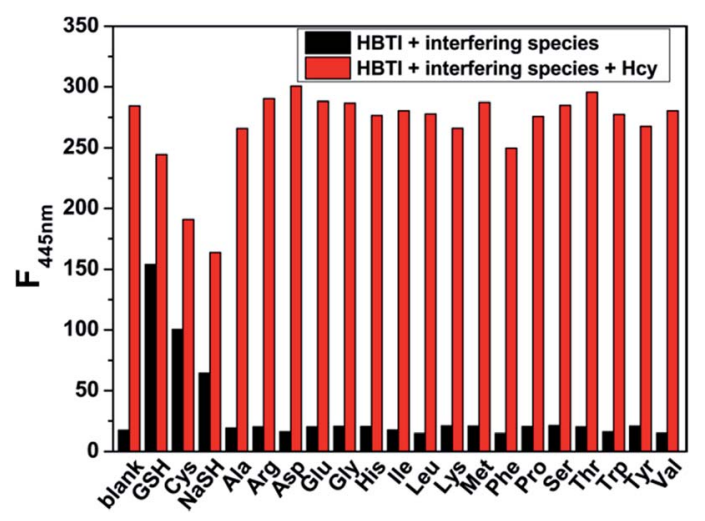

Fig. 5 Fluorescence intensity at $445 \mathrm{~nm}$ of probe $\mathrm{HBTI}(10 \mu \mathrm{M})$ toward Ala, Arg, Asp, Glu, Gly, His, lle, Leu, Lys, Met, Phe, Pro, Ser, Thr, Trp, Tyr, Val and NaSH (various analytes: $100 \mu \mathrm{M}$; GSH: 1 mM; Cys: $200 \mu \mathrm{M}$ ) in the absence and presence of Hcy $(50 \mu \mathrm{M})$ in PBS buffer $(10 \mathrm{mM}, \mathrm{pH} 7.4$, containing $1 \% \mathrm{CH}_{3} \mathrm{CN}, \mathrm{v} / \mathrm{v}$ ) at $25^{\circ} \mathrm{C}$. $E_{\mathrm{x}}=385 \mathrm{~nm}, d_{\mathrm{ex}}=d_{\mathrm{em}}=3 \mathrm{~nm}$.

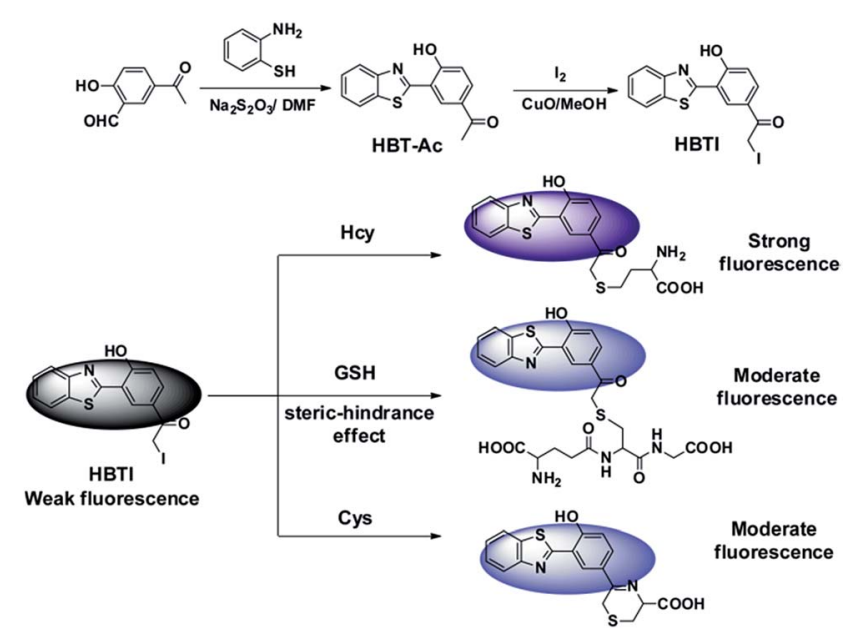

Scheme 1 Synthesis route of the target fluorescent probe HBTI and the possible reaction mechanism with Hcy/GSH/Cys.

incubated with probe HBTI $(10 \mu \mathrm{M})$ for $30 \mathrm{~min}$ and then treated with Hcy $(50 \mu \mathrm{M})$ for another $30 \mathrm{~min}$. The cells exhibited strong blue fluorescence as shown in Fig. 6. Meanwhile, we also evaluated the cytotoxicity of the probe with different concentrations using a standard CCK-8 assay. ${ }^{13}$ The experiment results showed that the cell viability kept above $90 \%$, which suggested that the probe exhibited low cytotoxicity to the culture cells (Fig. S7 †). All these results clearly demonstrated that the probe was capable of detecting biothiols in living cells.

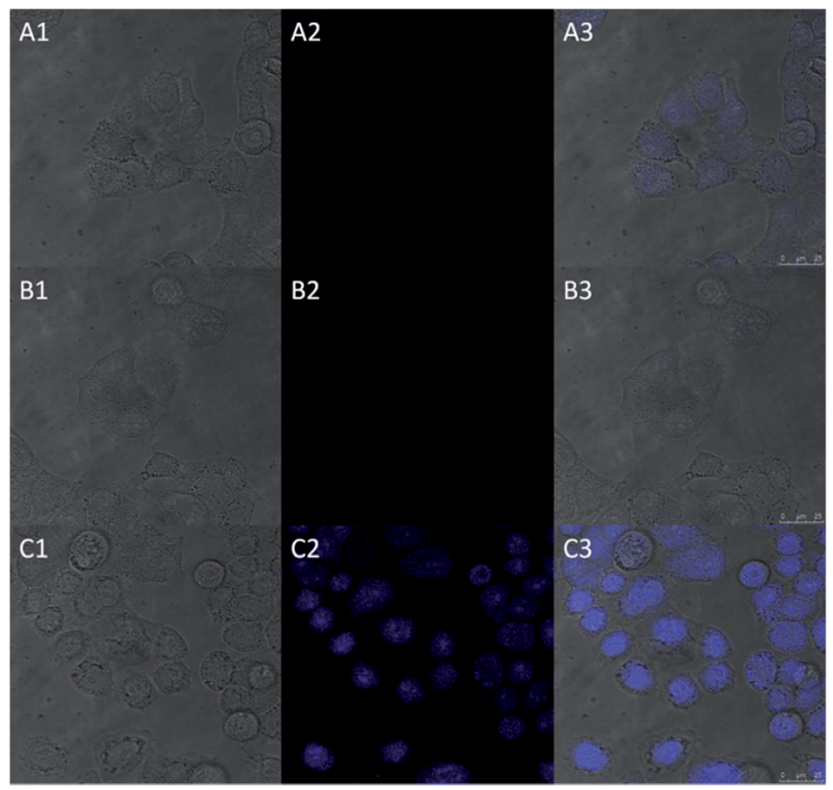

Fig. 6 CLSM fluorescence images $\left(d_{\mathrm{ex}}=405 \mathrm{~nm}\right.$ ) of HeLa cells. (A) Cells incubated with only probe $\mathrm{HBTI}$; $(\mathrm{B})$ cells were pretreated with $0.5 \mathrm{mM}$ NEM for 30 min and then treated with $10 \mu \mathrm{M}$ probe HBTI for another $30 \mathrm{~min}$; $(C)$ cells were treated with $0.5 \mathrm{mM}$ NEM for $30 \mathrm{~min}$ followed by treatment with $10 \mu \mathrm{M}$ probe HBTI for 30 min and $50 \mu \mathrm{M}$ Hcy for another $30 \mathrm{~min}$. The (1) bright field; (2) blue channel (427-512 $n m$ ); (3) merged images of (1) and (2). 


\section{Conclusions}

In conclusion, we have successfully developed a new type of turn-on fluorescent probe for Hcy by ESIPT and heavy atom effect strategy. The probe can discriminate Hcy from other related interfering species with high selectivity. Meanwhile, the probe shows a fast fluorescence response to Hcy in 15 min with a low detection limit of $1.6 \times 10^{-7} \mathrm{M}$. More importantly, the probe can be applied to detect Hcy in HeLa cells with low cytotoxicity. The preliminary cell experiment results indicated the probe could be used as a useful tool for detection of Hcy in living cells.

\section{Acknowledgements}

This work was supported by the National Natural Science Foundation of China (NSFC 21602051, 21575097, 21375092), the Natural Science Foundation of Hubei Province (2016CFB200) and the Key Project of the Education Department of Hubei Province (No. Q2015010).

\section{References}

1 (a) D. M. Townsend, K. D. Tew and H. Tapiero, Biomed. Pharmacother., 2004, 58, 47; (b) S. Zhang, C. N. Ong and H. M. Shen, Cancer Lett., 2004, 208, 143.

2 H. Tapiero, D. M. Townsend and K. D. Tew, Biomed. Pharmacother., 2003, 57, 134.

3 S. Seshadri, A. Beiser, J. Selhub, P. F. Jacques, I. H. Rosenberg, R. B. D'Agostino, P. W. F. Wilson and P. A. Wolf, N. Engl. J. Med., 2002, 346, 476.

4 S. Shahrokhian, Anal. Chem., 2001, 73, 5972.

5 J. Lasierra-Cirujeda, P. Coronel, M. J. Aza and M. Gimeno, J. Blood Med., 2013, 4, 31.

6 (a) B. K. Rani and S. A. John, Biosens. Bioelectron., 2016, 83, 237; (b) Y. Liu, X. Lv, M. Hou, Y. Shi and W. Guo, Anal. Chem., 2015, 87, 11475; (c) V. V. S. Mummidivarapu, D. S. Yarramala, K. K. Kondaveeti and C. P. Rao, J. Org. Chem., 2014, 79, 10477.

7 (a) L. Zhang, M. Li, C. Zhao and X. Gu, Tetrahedron Lett., 2016, 57, 578; (b) X. Han, F. Yu, X. Song and L. Chen, Chem. Sci., 2016, 7, 5098; (c) B. Gao, L. Cui, Y. Pan, G. Zhang, Y. Zhou, C. Zhang, S. Shuang and C. Dong, RSC $A d v .$, 2016, 6, 43028; (d) M. Cao, H. Chen, D. Chen, Z. Xu, S. H. Liu, X. Chen and J. Yin, Chem. Commun., 2016, 52, 721; (e) L. Song, H. Tian, X. Pei, Z. Zhang, W. Zhang and J. Qian, $R S C A d v$., 2015, 5, 59056; (f) L. Y. Niu, Q. Q. Yang, H. R. Zheng, Y. Z. Chen, L. Z. Wu, C. H. Tung and Q. Z. Yang, $R S C A d v$., 2015, 5, 3959; $(g)$ D. Lee, G. Kim, J. Yin and J. Yoon, Chem. Commun., 2015, 51, 6518; (h)
X. F. Yang, Q. Huang, Y. Zhong, Z. Li, H. Li, M. Lowry, J. O. Escobedo and R. M. Strongin, Chem. Sci., 2014, 5, 2177. 8 (a) J. Zhang, Y. Lv, W. Zhang, H. Ding, R. Liu, Y. Zhao, G. Zhang and Z. Tian, Talanta, 2016, 146, 41; (b) Y. Qu, X. Zhang, L. Wang, H. Yang, L. Yang, J. Cao and J. Hua, $R S C A d v .$, 2016, 6, 22389; (c) W. Niu, L. Guo, Y. Li, S. Shuang, C. Dong and M. S. Wong, Anal. Chem., 2016, 88, 1908; (d) X. Liu, D. Yang, W. Chen, L. Yang, F. Qi and X. Song, Sens. Actuators, B, 2016, 234, 27; (e) C. Chen, W. Liu, C. Xu and W. Liu, Biosens. Bioelectron., 2016, 85, 46; (f) A. R. Sarkar, C. H. Heo, E. Kim, H. W. Lee, H. Singh, J. J. Kim, H. Kang, C. Kang and H. M. Kim, Chem. Commun., 2015, 51, 2407.

9 (a) X. Dai, T. Zhang, J.-Y. Miao and B. X. Zhao, Sens. Actuators, $B$, 2016, 223, 274; (b) S. Areti, S. K. Verma, J. Bellare and C. P. Rao, Anal. Chem., 2016, 88, 7259; (c) J. Zhang, B. Yu, L. Ning, X. Zhu, J. Wang, Z. Chen, X. Liu, X. Yao, X. Zhang and H. Zhang, Eur. J. Org. Chem., 2015, 2015, 1711; (d) W. Jiang, H. Chen, Y. Pan and W. Lin, Anal. Methods, 2015, 7, 4168; (e) S. Areti, R. Teotia and C. P. Rao, Analyst, 2015, 140, 7391.

10 (a) R. K. Pathak, J. Dessingou and C. P. Rao, Anal. Chem., 2012, 84, 8294; (b) J. Dessingou, A. Mitra, K. Tabbasum, G. S. Baghel and C. P. Rao, J. Org. Chem., 2012, 77, 371; (c) R. K. Pathak, V. K. Hinge, M. Mondal and C. P. Rao, J. Org. Chem., 2011, 76, 10039; (d) R. Kumar Pathak, K. Tabbasum, V. Kumar Hinge and C. Pulla Rao, Chem.Eur. J., 2011, 17, 13999; (e) R. Joseph, B. Ramanujam, A. Acharya and C. P. Rao, J. Org. Chem., 2009, 74, 8181.

11 (a) Y. W. Wang, S. B. Liu, W. J. Ling and Y. Peng, Chem. Commun., 2016, 52, 827; (b) L. Tang, J. Shi, Z. Huang, X. Yan, Q. Zhang, K. Zhong, S. Hou and Y. Bian, Tetrahedron Lett., 2016, 57, 5227; (c) N. Zhao, Q. Gong, R. X. Zhang, J. Yang, Z. Y. Huang, N. Li and B. Z. Tang, J. Mater. Chem. C, 2015, 3, 8397; (d) J. Zhang, X. D. Jiang, X. Shao, J. Zhao, Y. Su, D. Xi, H. Yu, S. Yue, L.-j. Xiao and W. Zhao, RSC Adv., 2014, 4, 54080; (e) H. Y. Lee, Y. P. Choi, S. Kim, T. Yoon, Z. Guo, S. Lee, K. M. K. Swamy, G. Kim, J. Y. Lee, I. Shin and J. Yoon, Chem. Commun., 2014, 50, 6967; (f) S. Chen, Y. Hong, J. Liu, N.-W. Tseng, Y. Liu, E. Zhao, J. W. Yip Lam and B. Z. Tang, J. Mater. Chem. B, 2014, 2, 3919; $(g)$ W. Wang, J. O. Escobedo, C. M. Lawrence and R. M. Strongin, J. Am. Chem. Soc., 2004, 126, 3400.

12 L. He, Q. Xu, Y. Liu, H. Wei, Y. Tang and W. Lin, ACS Appl. Mater. Interfaces, 2015, 7, 12809.

13 (a) Z. Chen, F. Chen, Y. Sun, H. Liu, H. He, X. Zhang and S. Wang, RSC Adv., 2017, 7, 2573; (b) Y. Lv, P. Liu, H. Ding, Y. Wu, Y. Yan, H. Liu, X. Wang, F. Huang, Y. Zhao and Z. Tian, ACS Appl. Mater. Interfaces, 2015, 7, 20640. 